\title{
XXXII CONGRESSO BRASILEIRO DE ENFERMAGEM
}

José Néri da Silveira*

ReBEn/01

SILVGIRA, J.N. - XXXII Congresso Brasileiro de Enfermagem. Rev. Bras. Enf.; DF, $34: 3-5,1981$.

A Associação Brasileira de Enfermagem confere-me inexcedível distinção, em me recebendo no seio de sua comunidade, como Membro Honorário. Estou consciente da extrema prodigalidade do gesto, bem como da inafastável desproporção entre a alta honraria e o nenhum merecimento, para tanto, do agraciado. Como escreveu, porém, o autor de "O Pequeno Príncipe", "quando o mistério se nos depara impressionante, a gente não ousa desobedecer".

Justificadamente, não poderia imaginar o então jovem advogado, quando, a 15 de janeiro de 1957 , na cidade de Porto Alegre, recebeu, em consulta profissional, no seu escritório, a uma jovial quartanista da Escola de Enfermagem, da Capital gaúcha, que, aí, se estaria plantando o marco inicial, o instante primeiro desta noite solene e plena de agradáveis reminiscências. Tratava-se, segundo a consulente, de uma controvérsia que se instalara entre a direção de sua Escola, à época, anexa à Faculdade de Medicina de Porto Alegre, e o Diretor deste estabelecimento, em virtude da exoneração da
Diretora e Vice-Diretora da Escola de Enfermagem. As dezesseis concluintes da Quarta Turma de Enfermeiras gaúchas pretendiam a permanência da Diretora e Vice-Diretora de sua Escola. Percebi, então, no desdobrar das entrevistas, pelo entusiasmo das jovens, pelo ardor de sua atitude solidária às mestras, que sustentavam injustiçadas, não só o anseio por uma afirmação profissional e pela autonomia de sua Escola, mas ainda a segurança com que debatiam os princípios de sua ciência, destinada a conviver com as demais que se conumeram no campo da saúde. Empolgando-se com a causa, o jovem advogado manuseou livros e revistas de enfermagem que as simpáticas constituintes lhe trouxeram. Em longo memorial, ei-lo a argumentar quanto ao caráter científico da Enfermagem, a autonomia dessa ciência nos dias em curso, a necessidade de possuir ensino, com direção e orientação exclusivas de enfermeiros, cumprindo, em conseqüência, ser respeitada a autonomia de suas Escolas, sob os pontos de vista administrativo e didático. Como

* Presidente do Tribunal Federal de Recursos - Discurso de agradecimento - Bras1lia - Distrito Federal - XXXII Congresso Erasileiro de Enfermagem - 5/6/80. 
seria curial, não faltaram, no trabalho, as citações ao sistema da imortal FLCRENCE NIGHTINGALE. O arrazoado, todavia, não logrou êxito. Recebidas pelo sisudo Diretor, as jovens estudantes experimentaram, entretanto, o dissabor da derrota. As organizadoras de sua Escola caíram, de pé, numa postura característica dos que lutam e quedam por um ideal autenticamente humano, nobre e justo.

Do episódio, é certo, houve somente um grande beneficiário. $\mathrm{O}$ jovem advoi gado perdeu a causa, mas recebeu a mais gratificante de todas as recompensas de sua vida: dentre as integrantes da Turma de Enfermeiras de 1957, de Porto Alegre, saiu a sua esposa, mãe de seus sete filhos, dos quais a primogênita já é também estudante de Enfermagem, da Universidade Federal cỏo Río Grande do Sul.

Embora dedicado, constantemente. às lides da Jurisprudência, desde aí, de modo especial, por força dessas circunstâncias, para mim tão felizes, a causa da Enfermagem tem eíetivamente estado dentro de meu coração.

Bem podeis, assim, avaliar, Senhoras Enfermeiras e Senhores Enfermeiros, o quanto me sensibiliza o títuio que me concedeis. A Associação Brasiieira de Enfermagem, com quase cinqüenta anos de existência, congrega a comunidade científica e intelectual da Enfermagem brasileira, realizando obra cultural de extraordinário merecimento, de que este magnífico XXXII Congresso Brasileiro é exempio assinalado. Promovendo o desenvolvimento da Enfermagem no Brasil, contribui também para a melhoria dos padrões de seu ensino, reafirmando rumos do exercício profissional, buscando o aprimoramento de seus membros e sendo, em conseqüência de tudo isso, instrumento eficaz a serviço da melhoria da assistência à saúde de nosso povo.

Como efeito, de seu espírito de ação, sem dúvida, já rssultaram não só os Sindicatos de Enfermeiros no Estado do Rio Grande do Sul e no Rio de Janeiro, para citar os primeiros, mas, ainda, os órgãos de natureza esiatal, visando à disciplina profissional, que são os Conselhos Federal e Regionais de Enfermagem, também modelarmente organizados, segundo o senticio de ordem, de objetividade e de segurança, tão entranhado na nobreza da alma do enfermeiro.

Busca, é exato, a Enfermagem no Brasil, por intermédio de suas entidades representativas e de suas lideranças, a defin:ção de itinerários mais precisos e consentâneos com o progresso de sua ciência, para a ação como profissão liberal. É, hoje, ponto assente que a atenção à saúde constitui problema multiprofissional. O enfermeiro, como integrante da equipe de saúde, tende, também, já o proclamou em 1975 a Crganização Mundial da Saúde, à promoção, proteção e recuperação da saúde da pessoa, da família e da comunidade, sendo justo, dessarte, reconheccr a necessidade de sua presença no planejamento e programação das instituiçōes e serviços de saúde, asssegurando-lhe, outrossim, autonomia técnica no planejamento, organização, execução e avaliação da assistência específica de enfermagem. Daí por que, no particular, penso que foi, com inteira propriedade, que sinalou a culta professora e ilustre Enfermeíra, Dra. ROSALDA CRUZ NOGUEIRA PAIM, Em seu livro "Metodologia Científica em Enfermagem", págs. 104/105, referindose à legislação reguladora das atribuições do Enfermeiro (Lei n.o 775/49, Lei n. ${ }^{\circ} 2.604 / 55$ e Decreto n. $\left..^{\circ} 50.387 / 61\right)$ : "Com o perpassar dos anos e a evolução da enfermagem e do enfermeiro, não mais correspondem (esses diplomas) aos objetivos a que se propuseram, necessitando assim de reajuste, por isso que se espera para breve a elaboração, pelo Congresso, de Lei que reformule essa legislação ultrapassada e obsoleta (' ')". 
A obra legislativa que, nesse sentido, por certo, se realizará, em futuro próximo, há de constituir, dessa maneira, instrumento eficiente a proporcionar novos desenvolvimentos da Enfermagem, nos domínios da ciência, da pesquisa, das técnicas, do ensino e do controle do exercício profissional, o que, em tudo, concorrerá para a grandeza da profissão e o cumprimento cie sua missão social. Nessa linha, de outra parte, cumpre não perder de vista. também, a indiscutível conveniência de se tornar cada vez mais harmônica a inter-relação entre as diversas profissões, que aplicam as ciências da saúde, əm ordem a coexistirem num lúcido $\mathrm{e}$ saudável espírito de compreensão, conscientes todos de que é somente no convívio feliz dos diferentes profissionais Ia saúde que cada categoria poderá lograr a plenitude de seus objetivos e a Pátria comum alcançar a saúde geral de seu povo.

Sou profundamente agradecido à culta e abnegada Enfermeira, Dra. Mi- riam Graça Generoso Pereira, intérprete da ABEn, neste instan'te, pelas palavras de generosidade e de extrema bondade com que me saudou em hora de emoção. Já se disse que a enfermeira é uma professora da saúde, pela relação direta entre a confiança que inspira. a solidez de seu preparo e a eficiência de seu ensino. Além de tudo isso, a Dra. Míriam Graça Generoso Pereira, em slias palavras amigas e cordialíssimas, evidenciou terem realizado, em si, as enfermeiras do Brasil, também, o ideal indicado por FLORENCE NIGHTINGALE ao escrever: "A enfermeira deve ser... possuidora de sentimentos elevados e delicados."

Muito obrigado!

(Discurso proferido pelo Ministro JOSÉ NERI DA SILVEIRA, no XXXII Congresso Brasileiro de Enfermagem, no Centro de Convenções em Brasília, a 5-6-1980, agradecendo o título de "Membro Honorário" da ABEn). 